\title{
Surface Phenomena: A Cornerstone of Iron and Steelmaking Processes
}

\author{
Michel OLETTE
}

Formerly IRSID, France.

(Based on the Yukawa Memorial Lecture held at Yokohama National University, Yokohama, on March 31, 1993)

Mr. Masao YUKAWA was a very prominent personality of the Japanese Iron and Steel Industry. This year, on his 90 th birthday, I am pleased to contribute to acknowledge the very important part he played in the spectacular development of Iron and Steel Technology in Japan, which was also taken as a lesson in many industrial countries in the world.

As a good example of his spirit of international cooperation, it is worthwhile to mention his participation in the construction of the USIMINAS steel plant in Ipatinga, Brazil, which I had the opportunity to visit and to see in successful operation some years ago.

It is, for me, a great honour to have been invited to join, in 1993, the very impressive list of distinguished YUKAWA Memorial Lecturers.

As Masao YUKAWA had a very wide perspective of Iron and Steelmaking Processes, I will try to day, in memory of him, to show the importance of Surface Phenomena, a real "cornerstone", in pyrometallurgical processes involved in steel production.

\section{Introduction}

Most of the important chemical reactions involved in pyrometallurgical methods, and particularly in iron and steelmaking processes, are essentially heterogeneous. The different phases taking part in these reactions are separated by interfaces through which various substances must move.

The intention of this review is to try to give a synthetic idea of our present knowledge of the important role played by interfacial phenomena (at high temperature) in iron and steelmaking operations.

Various aspects of these interfacial phenomena have been examined by many authors, from the first decades of the $\mathrm{XX}^{\text {th }}$ century.

The first of them was very likely Darken, when pointing out the importance of the extent of interfacial areas in discussing rates and kinetics of the open hearth reaction, ${ }^{1,2)}$ as it was mentioned at the Darken conference $^{3)}$ by Elliott, the 1974 Yukawa Memorial Lecturer. Pioneering work in this field was also carried out by Kozakevitch who considered, in numerous papers, the surface properties of liquid metals and oxide melts, ${ }^{4-10)}$ and interfacial features between liquid metals and solid or liquid oxide phases. ${ }^{11-14)}$ This work was continued at IRSID for many years. ${ }^{15-18)}$

In 1971, Richardson, the first Yukawa Memorial Lecturer, published careful considerations on bubbles formation in extractive metallurgy. ${ }^{19,20)}$

More recently, research work was performed in the USA by Cramb et al. ${ }^{21,22)}$ and, to a larger extent, in Japan, where a special ISIJ Committee of Interfacial Transport Phenomena, created in 1986 and chaired by Tokuda ${ }^{23)}$ organized the activities of 5 working groups, which were summarized in the January 1992 special issue of ISIJ International.

Several prominent examples demonstrate the important controlling behaviour of interfacial phenomena in steelmaking reactions:

(1) Every steelmaker knows that the rate at which carbon monoxide bubbles nucleate and grow plays a dominant role in the dynamics of refining steel and this rate is largely controlled by interfacial properties: it must be remembered that in a $200 \mathrm{t}$ BOF converter, the total interface area was estimated to be more than $50000 \mathrm{~m}^{2}$ due to metal-slag emulsion formation. ${ }^{24)}$

Iron shot was found occasionally in blast furnace slags,

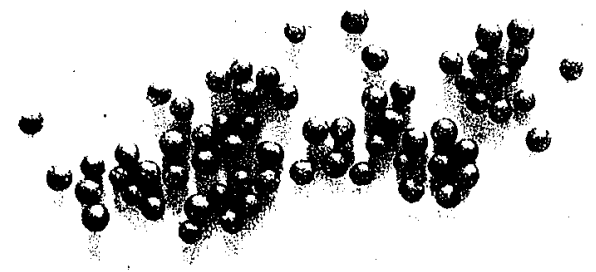

spheric drops.

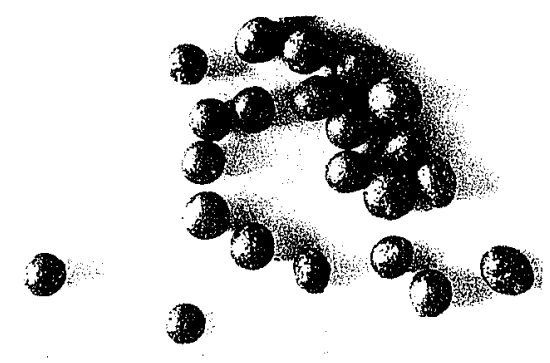

certain(descending)drops are elongated.
Fig. 1.

Iron shot extracted from a slag: 
but it can be very abundant in BOF slags and Fig. 1 shows droplets extracted from such a converter slag. $25,26,9)$

(2) Consequently, the expansion of molten slag by $\mathrm{CO}$ bubbles evolving from slag-metal interface, the slag-foaming, ${ }^{27,28)}$ can produce an overflow from the lip of the furnace, causing a metal loss and interruption of the operation. A similar foaming phenomenon is also observed in newly developed pretreatments of hot metal and bath smelting of $\mathrm{Fe}$ and $\mathrm{Cr}$ ore. ${ }^{29,30}$ )

(3) Adsorption precedes absorption and it is well established that the flux of nitrogen into liquid iron is strongly reduced by the presence of minute amounts of strongly adsorbed species such as oxygen and sulphur $^{31,16)}$ as shown on Fig. 2.

(4) In secondary metallurgy, the formation of solid inclusion clusters, coalescence of liquid inclusions and

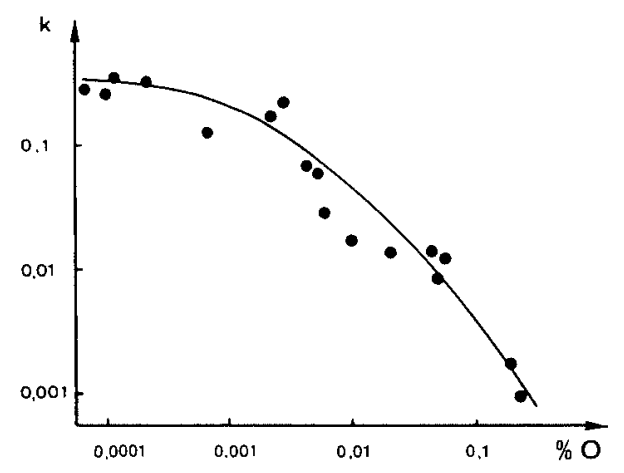

Fig. 2. Kinetics coefficient of nitrogen absorption in liquid iron as a function of oxygen content around $1550^{\circ} \mathrm{C}$.

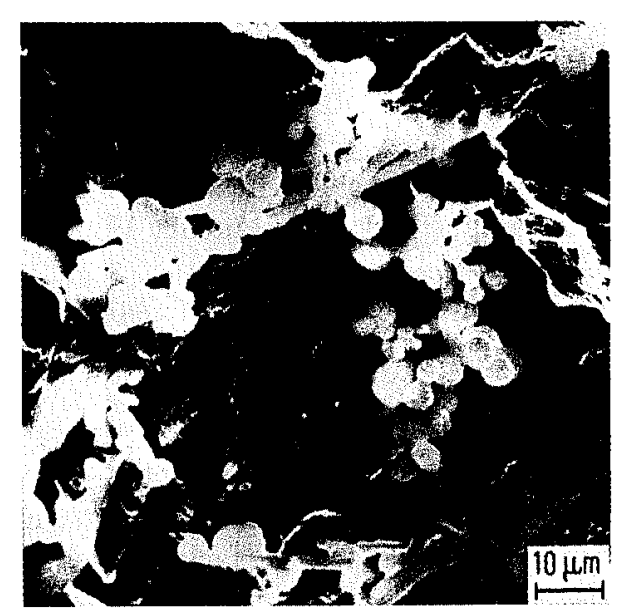

Fig. 3. Scanning electron microscope image of alumina clusters. possible elimination of both are much affected by interfacial phenomena: for example, wetting or contact angle values between liquid metal and oxide phase are quite determining. ${ }^{32,33,21)}$ Figure 3 presents an example of alumina inclusions clusters. ${ }^{33)}$

(5) Inclusions can be entrapped at a refractory interface and this phenomenon is responsible for nozzle blockage and also for the possibility of steel filtration using ceramic structures. ${ }^{21)}$

(6) There is much evidence that the interface between certain oxide phases and molten iron alloys may be upset by spontaneous interfacial motion. Kozakevitch, ${ }^{11,12,13,9)}$ was the first to observe such a phenomenon in a metallurgical operation (desulphurization of hot metal by a blast furnace slag) as illustrated by Fig.4. ${ }^{9)}$ Another example was given by Riboud and Lucas when an oxidizing slag is in contact with a liquid steel, rich in a strong deoxidizer such as Al. ${ }^{17)}$

(7) In the corrosion of refractory materials, preferential attack is often observed at gas/slag and slag/ metal phase boundaries as shown on Figure 5, 34-36) example mentioned by Richadson ${ }^{34)}$ of the corrosion of an alumina crucible by lead and a $\mathrm{SiO}_{2}-\mathrm{PbO}$ slag.

With regard to these erosion patterns traditionally referred to as "slag-line" or "flux-line" erosion, and, more generally, considering the spectacular increase of the mass transfer in some metallurgical reactions, the importance of Marangoni flows at the slag-metal interface, almost completely ignored for a long time, has been demonstrated these last 30 years by many authors. $^{37-40)}$

The purpose of this paper is to present a condensed overall survey of the various aspects of interface phenomena involved in the iron and steelmaking processes by considering successively the following topics:

- Quantitative approach of interfacial properties at equilibrium: surface tension of liquid iron alloys and slags, interfacial properties between liquid metal and oxide phases, including contact angles.

- Study of the evolution of interfacial properties during mass transfer: liquid metal/slag interface upset by spontaneous interfacial reaction and consideration of the role of the Marangoni effect in the interfacial turbulence.

- Examination of various examples along the steel production line: BOF steelmaking, secondary metallurgy including inclusions removal, nozzle blockage, corrosion of refractories.

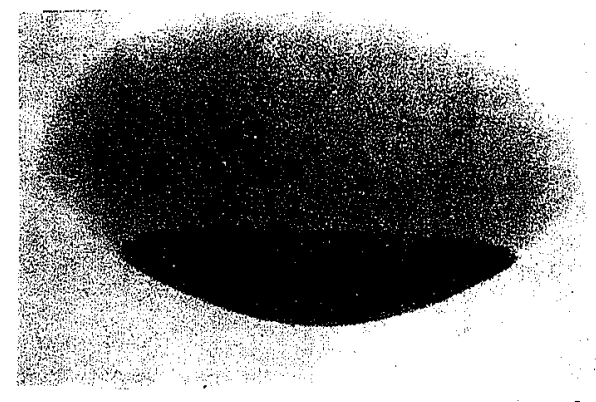

after a desulfurizing slag has been poured.

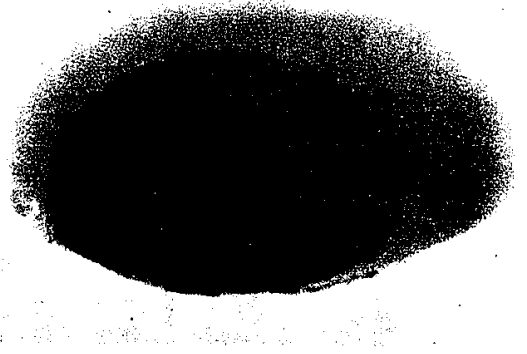

desulfurized drop
Fig. 4.

$\mathrm{X}$-ray photograph at $1500^{\circ} \mathrm{C}$ of a sulfur containing iron drop. 


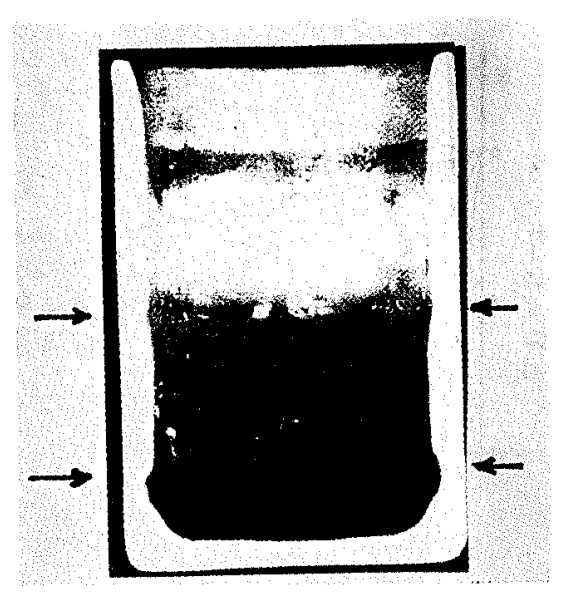

Fig. 5. Preferential attack of a laboratory crucible at the meniscus level slag/gas and metal/slag observed by F. D. Richardson.

\section{Quantitative Approach of Interfacial Properties at Equilibrium}

To understand interfacial phenomena in steelmaking, the necessary first step is to measure, as exactly as possible, surface properties at equilibrium: surface tension relative to the different liquid phases involved, contact angle and interfacial tension between liquid steel and relevant solid and liquid oxide materials. ${ }^{41,46)}$

\subsection{Iron}

The surface tension of pure liquid iron (and also that of most common metallic alloying elements) is very high: about $1800 \mathrm{mN} \cdot \mathrm{m}^{-1}$ at $1550^{\circ} \mathrm{C}(25$ times larger than the surface tension of water), as was found by Kozakevitch and Urbain, ${ }^{5,8,9)}$ using the sessile drop method.

When examining literature, values obtained from 1950 until now are extending from around 1400 to $2300 \mathrm{mN} \cdot \mathrm{m}^{-1} \cdot{ }^{43,44)}$ Data from recent and very careful measurements carried out by Jimbo and Cramb ${ }^{44)}$ induce these authors to propose:

$$
1905 \pm 50 \mathrm{mN} \cdot \mathrm{m}^{-1}
$$

By the way, it is interesting to take notice of a negative temperature coefficient of this surface tension $[-0.54$ $\mathrm{mN} \cdot \mathrm{m}^{-1} \mathrm{k}^{-1}$, after Schade et al. ${ }^{45)}$ ] which leads to a $\Upsilon_{\mathrm{Fe}}$ value of around $2200 \mathrm{mN} \cdot \mathrm{m}^{-1}$ at $1025^{\circ} \mathrm{C}$, in undercooled state.

Typically non-metals, and more generally the elements of " $B$ " columns of the periodic table, but particularly of the $\mathrm{VI}^{\text {th }}$ group, are highly surface active in liquid iron, as shown in the diagram of Fig. 6. . $^{5,8,41,42,46)}$ The strong surface activity of sulphur and oxygen is of particular interest in iron and steelmaking. ${ }^{11)}$

- Numerous investigators have studied the influence of oxygen, using different methods: sessile drop ${ }^{5,22)}$ pendant drop, maximum bubble pressure, or oscillating droplet, ${ }^{47)}$ and argon, helium, $\mathrm{H}_{2}-\mathrm{H}_{2} \mathrm{O}$, vacuum or $\mathrm{CO}-\mathrm{CO}_{2}$ as surrounding atmosphere. ${ }^{48}$ In Fig. 7, the results of Jimbo and $\mathrm{Cramb}^{44)}$ are compared to previous ones ${ }^{49,8,50)}$ and to calculated curve, drawn from Belton's equation, based on a combination of Gibbs and Langmuir isotherms, ${ }^{51,44)}$ in good agreement itself with Kasama et al. studies. ${ }^{47)}$

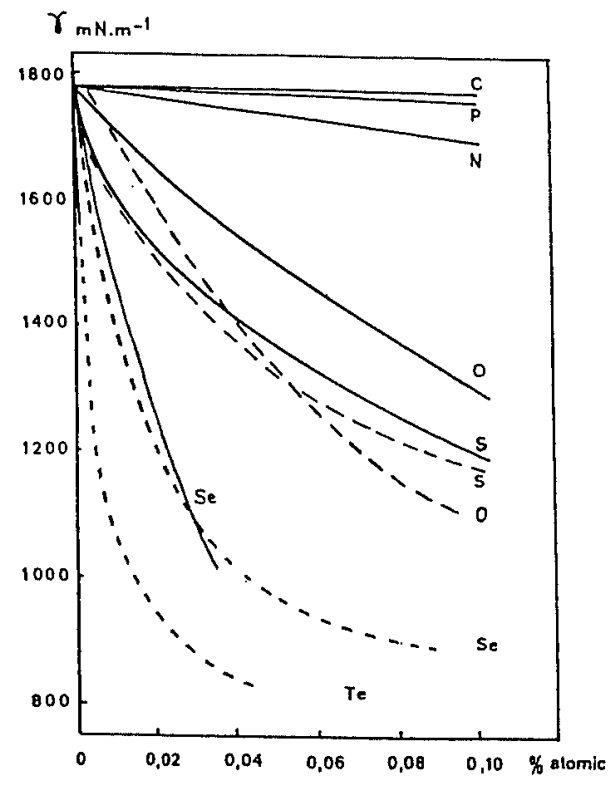

Fig. 6. Infiuence of additions on surface tension of liquid iron. Solid line shows the results measured at $1823 \mathrm{~K}$ by Kozakevitch. et al. Dotted line shows the results measured at $1873 \mathrm{~K}$ by Ogino et al.

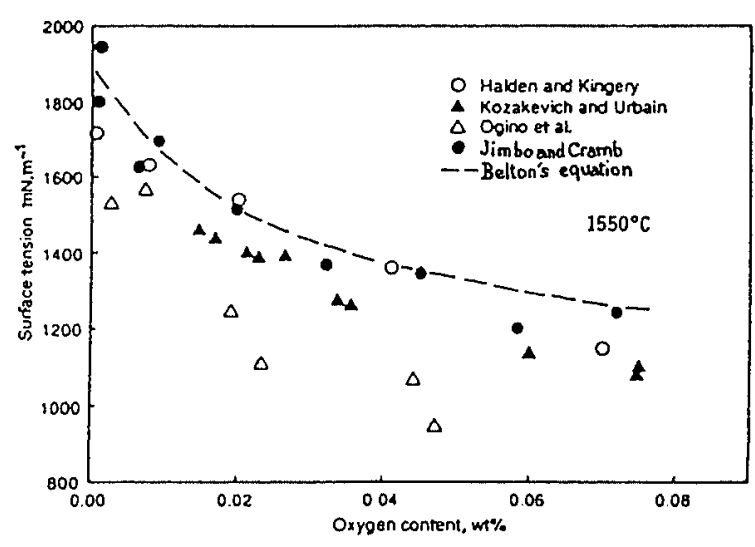

Fig. 7. Comparison of surface tension measurement for liquid iron as a function of oxygen content in metal.

Their apparent scatter could be a part of explanation of the discrepancy relative to the surface tension of "pure iron", the other reasons being relative probably to initial purity of the metal, pollution of it by the atmosphere or by contact with refractory materials, and temperature variations of the specimen (an increase of $50^{\circ} \mathrm{C}$ produces an increase of $Y_{\mathrm{Fe}}$ of 20 to $30 \mathrm{mN} \cdot \mathrm{m}^{-144,46)}$ ).

-The impressive lowering of the surface tension of liquid iron due to the increasing content of sulphur is presented in Fig. 8. ${ }^{18)}$ The curve represents the results of Kozakevitch et al.$^{8)}$ (for an oxygen activity around $30 \mathrm{ppm}$ ) as expressed by Belton formulation. ${ }^{51)}$ The number next to each point refers to the oxygen activity (in ppm). These results, obtained by Lucas ${ }^{18)}$ show that, at least at high sulphur content (above $0.1 \%$ ), an increase in oxygen content up to $400 \mathrm{ppm}$ does not significantly lower the surface tension, in slight disagreement with a work reported by Popel et al. ${ }^{52)}$ who found a decrease in surface tension larger in the ternary than in the binary, even at relatively low sulphur contents.

-Considering the influence of Carbon, there is also some 


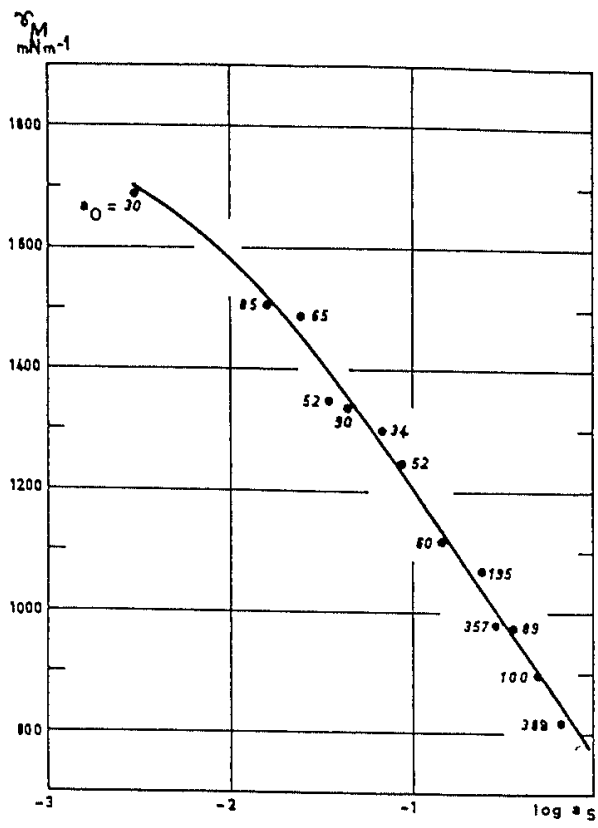

Fig. 8. Surface tension of $\mathrm{Fe}-\mathrm{S}-\mathrm{O}$ alloys at $1600^{\circ} \mathrm{C} v s$. sulphur actvity in logarithmic scale. Solid line is for $\mathrm{Fe}-\mathrm{S}$ alloys. The number close to each point refers to oxygen activity. (in ppm)

disagreement between previous studies, ${ }^{8}$ ) which reported an absence of evolution or a slight decrease, and more recent work ${ }^{44)}$ where $C$ is shown to cause a small increase of $Y_{\mathrm{Fe}}$ (of $30 \mathrm{mN} \cdot \mathrm{m}^{-1} / \mathrm{wt} \% \mathrm{C}$ ). A decrease of $\Upsilon_{\mathrm{Fe}}$, apparently due to carbon, could be explained by a possible contamination with trace amounts of sulphur when adding $\mathrm{C}$ to the melt.

-Very little is known on the surface tension of liquid steels, but major constituents of them: $\mathrm{Co}, \mathrm{Cr}, \mathrm{Ni}$ have high characteristics between 1500 and $1800 \mathrm{mN} \cdot \mathrm{m}^{-1}$ at melting point, except $\mathrm{Mn}: 1030 \mathrm{mN} \cdot \mathrm{m}^{-1}$ at $1550^{\circ} \mathrm{C} .{ }^{43)}$

\subsection{Oxide Systems and Slags}

In comparison with metals, the surface tension of liquid slags has not yet been so largely investigated, in spite of numerous recent studies.

Surface tension data for pure liquid oxides and slags are significantly lower than for metals: between 200 and $700 \mathrm{mN} \cdot \mathrm{m}^{-1}$, in absolute value. In binary systems based on liquid $\mathrm{FeO}$, Kozakevitch ${ }^{4)}$ has determined the surface tension decrease due to the addition of different oxides, using the dipping cylinder methods, see Fig. 9. $\mathrm{SiO}_{2}$, $\mathrm{CaO}, \mathrm{MnO}, \mathrm{TiO}_{2}$ lower it moderately. $\mathrm{Al}_{2} \mathrm{O}_{3}$ has a slight increasing effect and $\mathrm{Na}_{2} \mathrm{O}$ and $\mathrm{P}_{2} \mathrm{O}_{5}$ behave as capillarily active substances.

Considering ternary systems, it was found ${ }^{53)}$ see Fig. 10, that the surface tension of an equimolecular mixture is not much affected by the addition of $\mathrm{MgO}$ and $\mathrm{ZrO}_{2}$ but is lowered by the addition of $\mathrm{SiO}_{2}, \mathrm{TiO}_{2}$ and also $\mathrm{CaF}_{2}$ and $\mathrm{NaF}$ which have a sharper effect. ${ }^{53}$ )

For all basic slags containing silica, it seems that their surfaces have a tendancy to become richer in $\mathrm{SiO}_{2}$. It also worthwhile to mention that sulphur is very surface-active in silicate slags (as $\mathrm{S}^{-2}$ ions) but about four times less than in metals, on a molar basis. ${ }^{16)}$

A comprehensive report on surface tension of simple

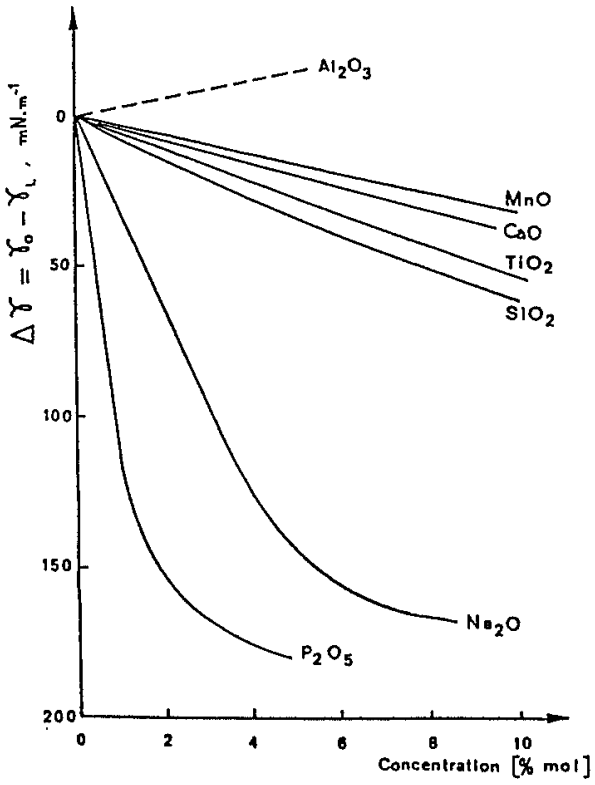

Fig. 9. Influence of additions in liquid $\mathrm{FeO}$ at $1420^{\circ} \mathrm{C}$ after Kozakevitch.

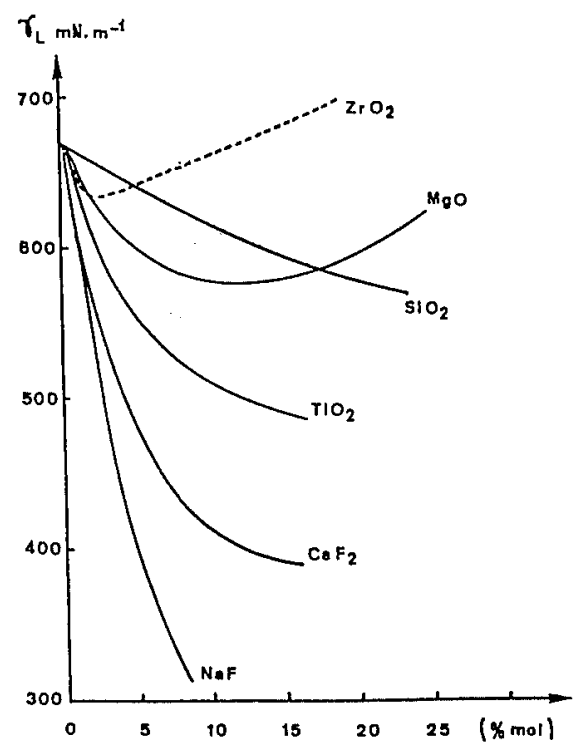

Fig. 10. Surface tension of $\mathrm{CaO}-\mathrm{Al}_{2} \mathrm{O}_{3}-\mathrm{Me}_{x} \mathrm{O}_{y}$ slags in $1610-1680^{\circ} \mathrm{C}$ temperature range after Evseev and Filippov.

oxides, fluorides and slags containing fluorides, was published some years ago by Keene and Mills. ${ }^{54)}$

\subsection{Equilibrium Interfacial Properties}

As already mentioned, the properties at interfaces between liquid iron alloys and metallurgical oxide phases are known to influence kinetics of many reactions occurring in the processing of iron and steel ${ }^{28,33)}$ and concerning the mass transfer between the two phases. ${ }^{41)}$

2.3.1. Contact Angle between Solid Materials and Liquid Phases

It is commonly observed that when a liquid is placed on a solid, it forms a droplet which has a specific equilibrium shape and contact angle (Fig. 11). The equilibrium contact angle $\theta$ is a measure of the ability of a liquid to wet a solid and varies from $0^{\circ}$ (complete 


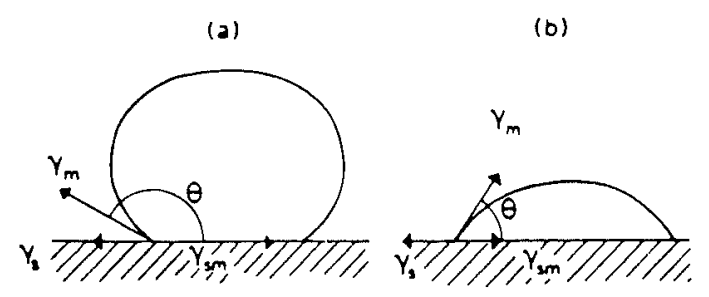

Fig. 11. Form of a droplet of metal resting on a solid oxide support. a) no wetting; b) wetting tendency

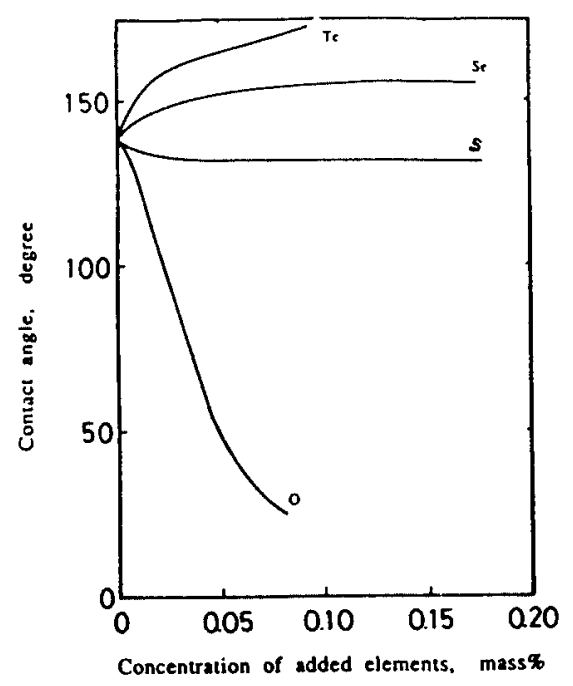

Fig. 12. Influence of added elements on contact angle of liquid iron on alumina at $1873 \mathrm{~K}$.

wetting) to $180^{\circ}$ (only one point of contact).

In the past, very careful measurements, using sessile drop method, carried out by Lucas at IRSID, ${ }^{14,32,33)}$ have shown that, for most of the pure oxides: $\mathrm{Al}_{2} \mathrm{O}_{3}$, $\mathrm{SiO}_{2}, \mathrm{CaO}, \mathrm{ZrO}_{2}, \mathrm{MgO}, \mathrm{La}_{2} \mathrm{O}_{3}$ but also for some aluminates and nitrides ( $\mathrm{TiN}, \mathrm{BN})$, the contact angle with pure liquid iron is larger than $90^{\circ}: 110 \pm 1^{\circ}$ for polished $\mathrm{Al}_{2} \mathrm{O}_{3}$ of very high purity, ${ }^{33)}$ Jimbo and $\mathrm{Cramb}^{44)}$ proposed $124^{\circ}$, in apparent agreement with previous data $\left(121^{\circ}-136^{\circ}\right)$.

The contact angle between liquid iron and $\mathrm{Al}_{2} \mathrm{O}_{3}$ change with concentrations of some surface active elements, as shown in Fig. 12: it decreases as the Oxygen concentration increases, but it increases when there is an increase in the Selenium and particularly in the Tellurium content. ${ }^{55)}$ Sulphur has little effect while at high oxygen concentrations, most refractory oxides tend to be wetted by liquid iron.

The contact angles between liquid slag and refractory materials have been recently reviewed by Nakashima and Mori, ${ }^{46)}$ Cramb and Jimbo. ${ }^{21)}$ They observed that liquid slags wet most refractories, especially when there is a tendency to react with each other, but they do not wet silicon carbide or graphite. Generally speaking, slags with higher $\mathrm{FeO}$ content have relatively lower contact angles.

\subsubsection{Interfacial Tensions between Iron-based Liquid Alloys and Slags}

Interfacial tension depends upon compositions of both liquid metal and oxide slag: In addition, their compositions can change because of reactions taking

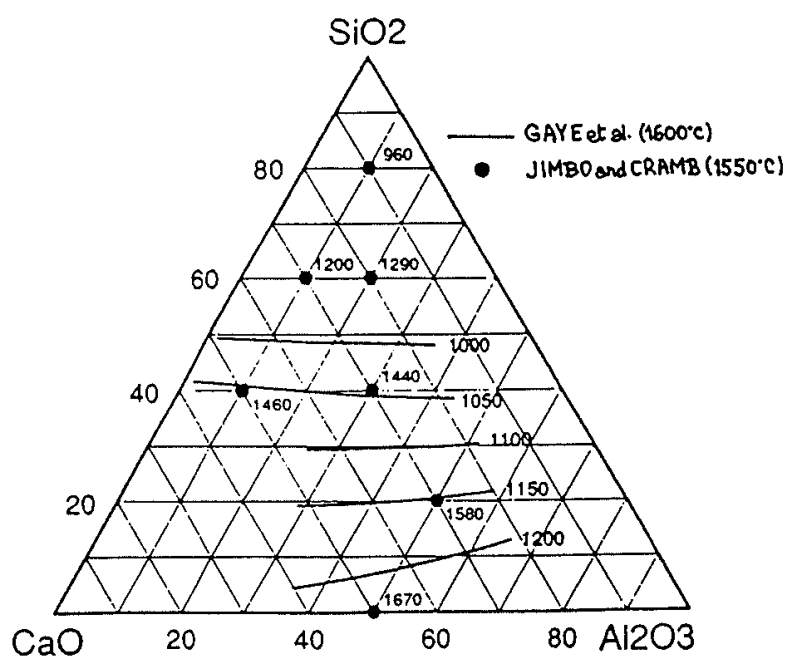

Fig. 13. Interfacial tension between liquid iron and liquid $\mathrm{CaO}-\mathrm{SiO}_{2}-\mathrm{Al}_{2} \mathrm{O}_{3}$ slag.

place after their contact, which introduce another source or uncertainty, in addition to difficulties dues to high temperature experimentation.

Many results which will be reported here have been obtained by making use principally of two experimental methods previously fully described:

- the X-ray observation of the profile of a sessile metal drop immersed in the slag, ${ }^{18,22,44)}$

- the observation of a slag droplet resting on its liquid metal substrate. ${ }^{15,18)}$

\section{Influence on Alloying Elements in Metal Phase}

Commercial steels contain many elements which have an influence on the interfacial tension. As it was mentioned by Nakashima and Mori, ${ }^{46)}$ from published data, except $\mathrm{W}$, the addition of all elements produces a decrease of the interfacial tension, their influence being more pronounced in this order: $\mathrm{Ni}, \mathrm{Mn}, \mathrm{Cr}, \mathrm{Mo}, \mathrm{Si}, \mathrm{P}$, C, V, Ti.

System $\mathrm{Fe}-\mathrm{O}-\mathrm{Si} / \mathrm{SiO}_{2}-\mathrm{CaO}-\mathrm{Al}_{2} \mathrm{O}_{3}-\mathrm{FeO}$ at $1600^{\circ} \mathrm{C}$

All experiments on this system were performed at IRSID using the method of the slag drop resting on a liquid metal substrate. ${ }^{15)}$ The results are reported on Fig. 13: the interfacial tension obtained, in good agreement with previous investigations, ${ }^{18)}$ show a decrease, as the $\mathrm{SiO}_{2}$ content in the slag is increased, from $1240 \mathrm{mN} \cdot \mathrm{m}^{-1}$ $\left(0 \% \mathrm{SiO}_{2}\right)$ to $1000 \mathrm{mN} \cdot \mathrm{m}^{-1}\left(50 \% \mathrm{SiO}_{2}\right)$ but part of these results can be attributed to an increase in metal oxygen content, as discussed later. On the same diagram, data from Jimbo and Cramb, ${ }^{22,44)}$ have been plotted for comparison. They are relative to "pure" iron droplets in contact with $\mathrm{CaO}-\mathrm{Al}_{2} \mathrm{O}_{3}-\mathrm{SiO}_{2}$ slags at $1550^{\circ} \mathrm{C}$. These last results are around 300 to $400 \mathrm{mN} \cdot \mathrm{m}^{-1}$ higher than the IRSID ones but they agree qualitatively with the influence of $\mathrm{SiO}_{2}$ concentration.

System $\mathrm{Fe}-\mathrm{O}-\mathrm{C} / \mathrm{SiO}_{2}-\mathrm{CaO}-\mathrm{Al}_{2} \mathrm{O}_{3}$

Figure 14 demonstrates the light surface active effect of silica at the interface liquid $\mathrm{Fe}-\mathrm{C}$ alloy $/ \mathrm{SiO}_{2}-\mathrm{CaO}-$ $\mathrm{Al}_{2} \mathrm{O}_{3}$ slag with the exception of $\mathrm{C}$ saturated iron, whose interfacial tension remains almost constant, whatever the silicon content may be in the slag. ${ }^{18)}$

It can be useful to precise that the contact angle 


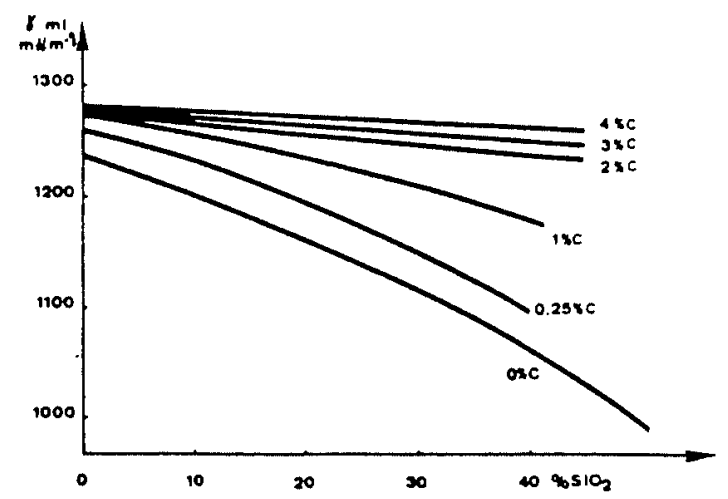

Fig. 14. Interfacial tension $\gamma_{m L}$ between $\mathrm{Fe}-\mathrm{C}$ alloys and $\mathrm{CaO}-\mathrm{SiO}_{2}-\mathrm{Al}_{2} \mathrm{O}_{3}$ slags.

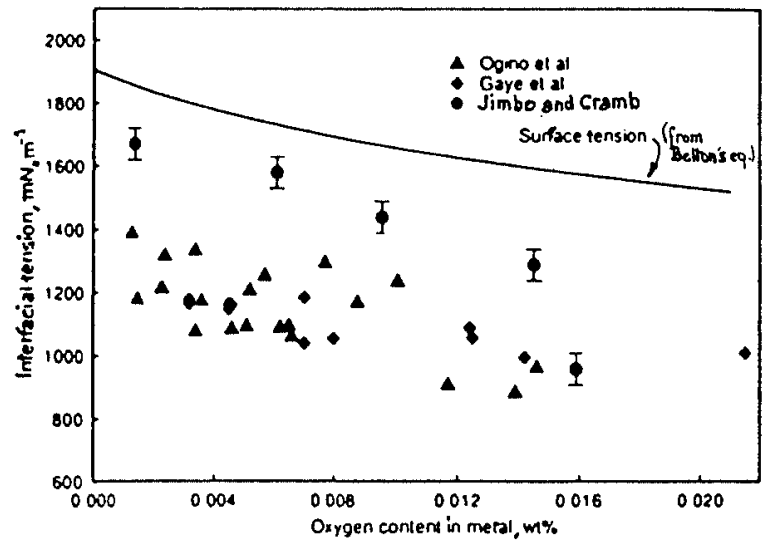

Fig. 15. Interfacial tension between liquid iron and liquid $\mathrm{CaO}-\mathrm{Al}_{2} \mathrm{O}_{3}-\mathrm{SiO}_{2}$ slags as a function of $\mathrm{SiO}_{2}$.

between slag and metal decreases from around $65^{\circ}$ for $\mathrm{SiO}_{2}$-free slags to about $15^{\circ}$ for slags with $50 \% \mathrm{SiO}_{2}$ whereas a variation of the $\mathrm{CaO} / \mathrm{Al}_{2} \mathrm{O}_{3}$ ratio, at constant $\mathrm{SiO}_{2}$ content, shows little effect.

\section{Influence of Oxygen and Sulphur in the Metal Phase}

A sensible effect of the oxygen concentration in the metal phase is shown in the Fig. 15 which presents three groups of results: from Ogino et al. ${ }^{50)}$ Gaye et al. ${ }^{18)}$ and Jimbo and Cramb. ${ }^{44)}$

All follow the trend that an increase of oxygen content in the iron phase produces a decrease of the interfacial tension. These data, when compared to the curve [drawn from Belton's equation ${ }^{51)}$ ], relative to surface tension of liquid $\mathrm{Fe}-\mathrm{O}$ alloy, show that the presence of a slag lowers the surface properties of the iron phase.

A more complete description of IRSID results ${ }^{18)}$ is presented in Fig. 16 in which interfacial tension values are expressed as a function of the oxygen activity in the metal phase. The solid curve represents the medium data for slags of the $\mathrm{CaO}-\mathrm{SiO}_{2}-\mathrm{Al}_{2} \mathrm{O}_{3}-\mathrm{FeO}$ system. ${ }^{18)}$ The dotted curve is derived from Ogino et al. study ${ }^{50)}$ for $\mathrm{CaO}-\mathrm{SiO}_{2}-\mathrm{FeO}$ system, in close agreement with IRSID results.

For compositions corresponding to continuous casting slags (30 to $60 \% \mathrm{SiO}_{2}$ ) containing $\mathrm{Na}_{2} \mathrm{O}$ and $\mathrm{CaF}_{2}$ (up to $15-20 \%$ ), the interfacial tensions (see Fig. 16) are higher at identical Oxygen activity (by about $200 \mathrm{mN}$. $\mathrm{m}^{-1}$ ), for large $\mathrm{CaF}_{2}$ contents, whereas $\mathrm{MnO}$ containing slags lead to lower interfacial values (a decrease of about

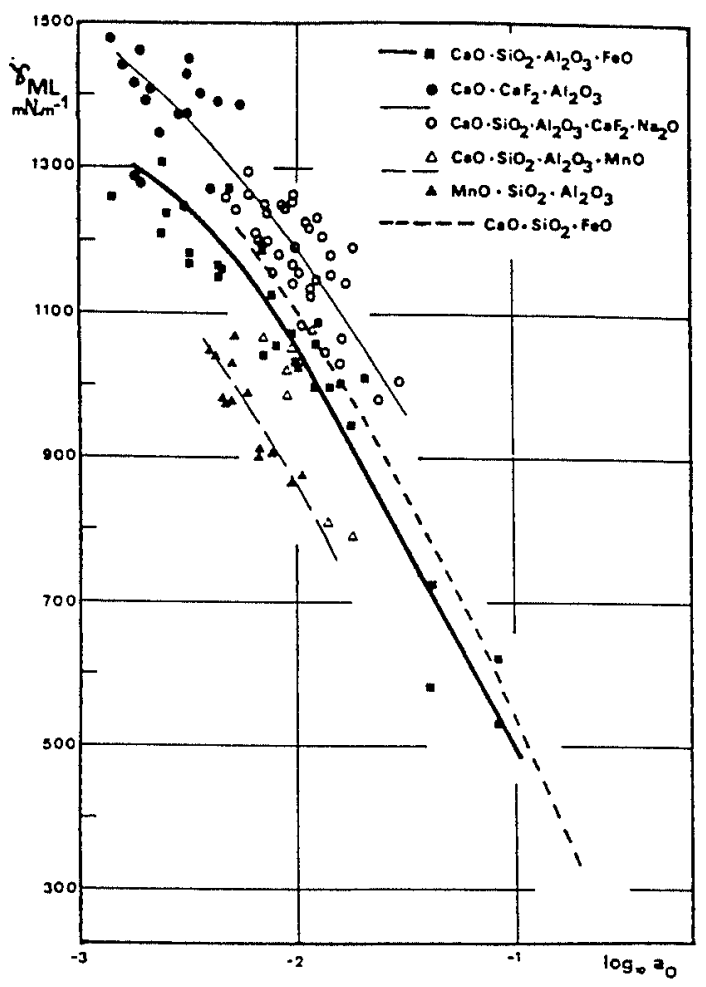

Fig. 16. Influence of oxygen activity on the interfacial tension between Fe-based liquid alloys and various slags at $1600^{\circ} \mathrm{C}$. The solid curve corresponds to $\mathrm{SiO}_{2}-$ $\mathrm{CaO}-\mathrm{Al}_{2} \mathrm{O}_{3}-\mathrm{FeO}_{x}$ slags, the dashed curve is given by Ogino et al. for $\mathrm{CaO}-\mathrm{SiO}_{2}-\mathrm{FeO}_{x}$ slags.

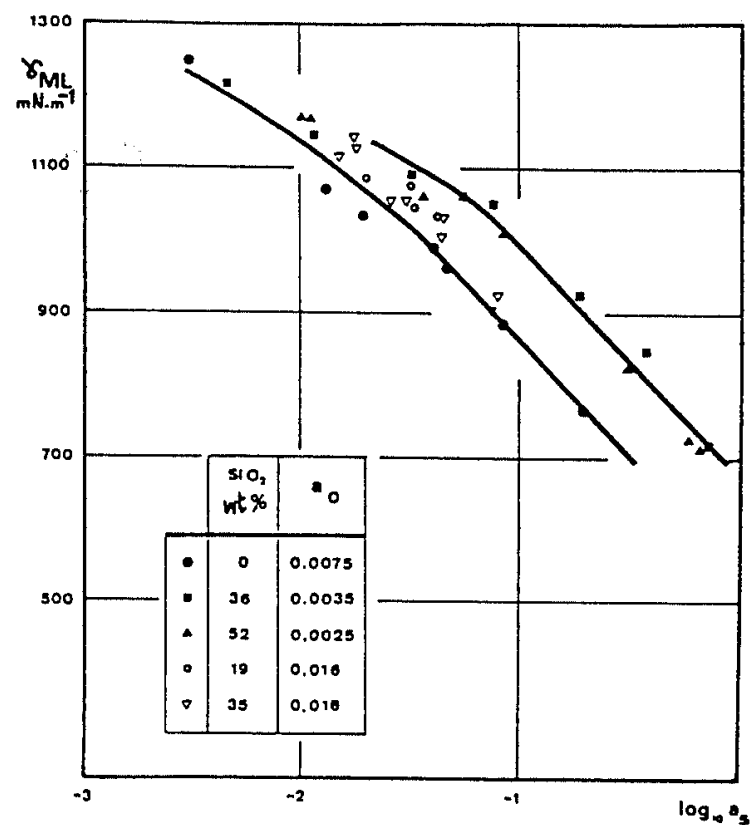

Fig. 17. Influence of sulphur activity on the interfacial tension between $\mathrm{Fe}-\mathrm{S}-\mathrm{O}-\mathrm{Si}$ liquid alloys and slags of the system $\mathrm{CaO}-\mathrm{SiO}_{2}-\mathrm{Al}_{2} \mathrm{O}_{3}-\mathrm{FeO}_{x}$ at $1600^{\circ} \mathrm{C}$.

$200 \mathrm{mN} \cdot \mathrm{m}^{-1}$, for the $\mathrm{MnO}-\mathrm{SiO}_{2}-\mathrm{Al}_{2} \mathrm{O}_{3}$ system).

To express the influence of sulphur in the metal phase, the interfacial properties between 5 slag compositions $\left(\mathrm{CaO} / \mathrm{Al}_{2} \mathrm{O}_{3}\right.$ close to 1 and $\% \mathrm{SiO}_{2}$ varying from 0 to $52 \%$ ) and $\mathrm{Fe}-\mathrm{S}-\mathrm{O}-\mathrm{Si}$ alloys with various Sulphur contents up to $0.7 \%$ are presented on Fig. 17 as a function of $\log _{10} a_{s}$. An almost linear decrease is observed for the 
$\mathrm{SiO}_{2}$ free slag, and similar trends exist for the other slag compositions. ${ }^{18)}$

Assuming that these decreasing effects on interfacial tension are simply attributed to oxygen or sulphur adsorption on the metal side of the interface, it is possible to estimate the excess oxygen or sulphur quantities, using the GIBBS adsorption isotherm: values of $15 \times 10^{-6}$ and $9 \times 10^{-6} \mathrm{~mol} \cdot \mathrm{m}^{-2}$ were found respectively for oxygen and sulphur, in satisfactory agreement with the values reported by various authors. ${ }^{18)}$

\section{Influence of Slag Composition}

Considering the influence of slag composition on the interfacial tension between liquid iron and slags, it was previously observed that $\mathrm{FeO}$ and $\mathrm{MnO}$ additions are producing a decrease in interface properties, ${ }^{18)}$ which is confirmed by the review paper published by Nakashima and Mori ${ }^{46)}$ who indicated also slight changes in interfacial tension due to the addition of $\mathrm{CaO}, \mathrm{BaO}, \mathrm{SiO}_{2}$ and $\mathrm{Al}_{2} \mathrm{O}_{3}$, but also a large decrease due to $\mathrm{P}_{2} \mathrm{O}_{5}$. El Gammal and Stracke have also reported strong decreasing effects of $\mathrm{Na}_{2} \mathrm{O}$ and $\mathrm{CaF}_{2}$ additions on the interfacial tension between liquid $\mathrm{CK} 45$ steel and $\mathrm{CaO}$ $\mathrm{SiO}_{2}-\mathrm{Al}_{2} \mathrm{O}_{3}$ slags, from measurements made by the drop detachment technique ${ }^{56)}$

\section{3. "Dynamic" Interfacial Properties during Mass Transfer}

The first clear evidence of a perceptible deformation of a metal/slag interface during intense mass transfer between the two phases was reported, as mentioned at the beginning of this review, by Kozakevitch ${ }^{11)}$ as soon as 1955, in the case of desulphurization of a liquid carbon alloy with a blast furnace slag.

This observation was confirmed by Minaev and Grigorian $^{57)}$ by Deryabin et al. ${ }^{58)}$ around 10 years later, and later on by Ooi et al. ${ }^{59)}$ The latter have observed the same phenomenon during the reactions of $\mathrm{Fe}-\mathrm{Al}$ alloys with $\mathrm{CaO}-\mathrm{Al}_{2} \mathrm{O}_{3}-\mathrm{SiO}_{2}$ slags and of $\mathrm{Fe}-\mathrm{Ti}$ alloys with $\mathrm{CaO}-\mathrm{Al}_{2} \mathrm{O}_{3}-\mathrm{TiO}_{2}$ slags. In these experiments, the deformation of the interface was noticed only when initial $\mathrm{Al}$ or Ti contents were higher than 4 and $7 \%$ respectively (see Fig. 18).

Kozakevitch $^{11)}$ attributed the interface deformation, and the consequent tendency towards spontaneous

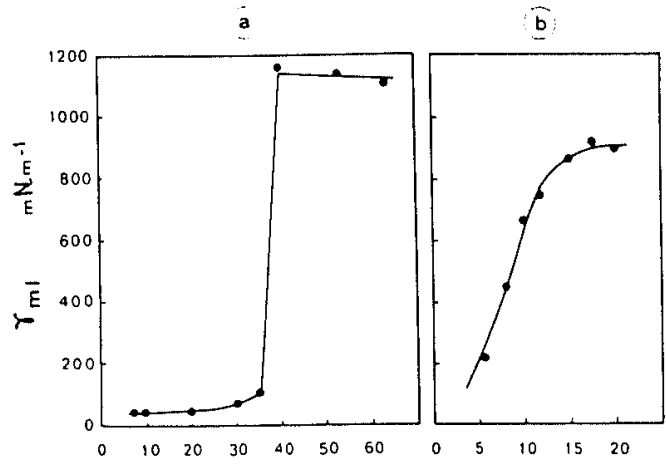

Fig. 18. Evaluation of interfacial tension $v s$. time, in minutes, after alloy addition: (from Ooi et al.)

a) between $\mathrm{Fe}-4 \% \mathrm{Al}$ alloy and $\mathrm{CaO}-\mathrm{SiO}_{2}-\mathrm{Al}_{2} \mathrm{O}_{3}$ slag b) between $\mathrm{Fe}-7.4 \% \mathrm{Ti}$ alloy and $\mathrm{CaO}-\mathrm{SiO}_{2}-\mathrm{TiO}_{2}$ slag emulsification to a drastic decrease in interfacial tension during mass transfer.

On the same line of thought, Defay and co-workers, ${ }^{60,61)}$ proposed a theoretical description of the interfacial layer by means of a model of equidistant planes which permits the calculation of the interfacial tension for any given distribution of matter.

According to this model, transitory states of zero interfacial tension can occur on account of opposite concentration gradients of two components in the interfacial layer.

A large number of experiments was conducted at IRSID $^{17,18)}$ to determine the conditions under which interfacial tensions seem to disappear. In most cases, the reactions corresponded to a reduction of the slag with elements dissolved in the metal phase and chemically active towards oxygen as $\mathrm{Al}, \mathrm{Ti}$, but also $\mathrm{Si}, \mathrm{P}, \mathrm{B}, \mathrm{Cr}$.

For all systems studied, a drastic decrease of dynamic interfacial tension was observed, provided slag-metal initial disequilibrium was large enough, ${ }^{17)}$ using direct $\mathrm{X}$-ray observation at high temperatures of the profile of a metal droplet immersed in a slag. Examples of X-ray images, characteristic of the main periods are presented in Fig. 19 ${ }^{17,18)}$ :

Progressive Lowering of Dynamic Interfacial Tension

The droplet immersed in the slag is observed to flatten progressively. The rate of reaction is not yet very high at this stage probably because of some oxidation of the droplet surface during preheating, and the computed interfacial tension does not reach very low values (Fig. 19(a).

Apparent Vanishing of Interfacial Forces

When the phenomenon is in its most intense form, the interface becomes roughly horizontal, see Fig. 19(b). Interfacial tension cannot be estimated at all. X-ray images suggest disturbance of the interface, which can be observed, after quenching, on a polished section (Fig. 19(d)).

\section{Recovery of High Interfacial Values}

When slag-metal reactions slow down, the interfacial tension rapidly recovers (Fig. 19(c)) a high value and the

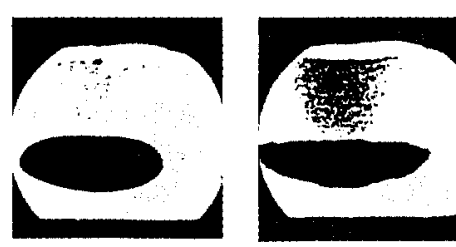

(b)

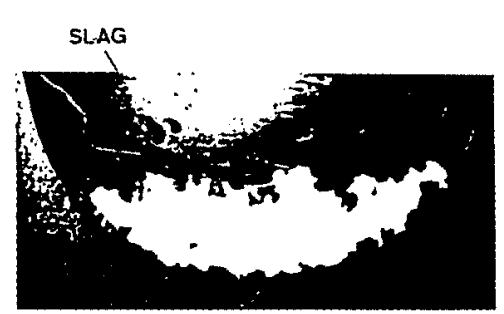

(d)
Fig. 19. Successive $X$-ray pictures of the profile of a metal droplet immersed in a slag, after: a) $7 \mathrm{~min}$; b) $18 \mathrm{~min}$; c) $40 \mathrm{~min}$; d) polished section, after quenching of a droplet corresponding to configuration $b$ ). 

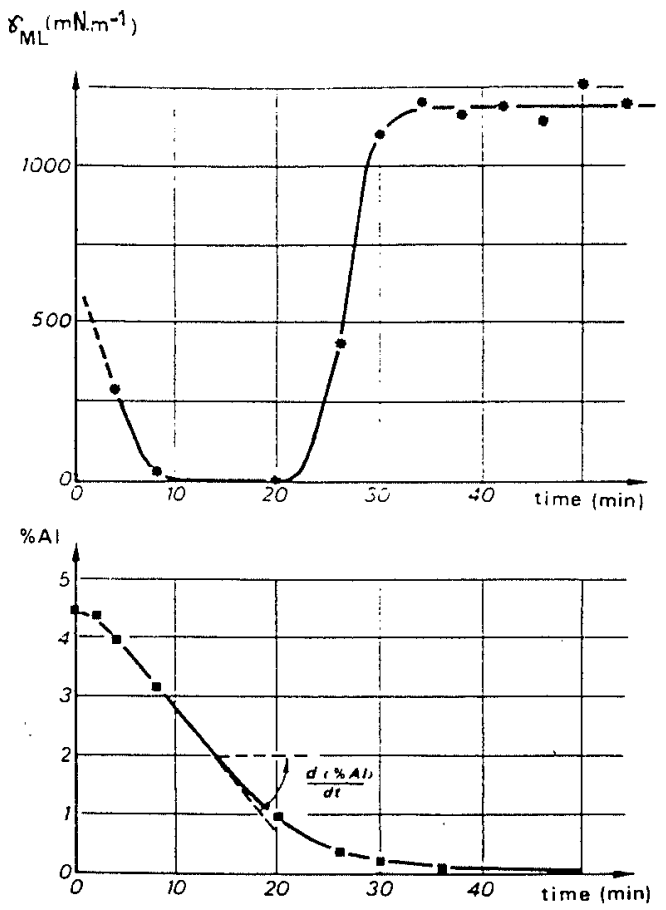

Fig. 20. Interfacial tension (upper part) and metal aluminum content (lower part) as a function of time: metal initial composition: $\mathrm{Fe}-4.45 \% \mathrm{Al}$; slag $\mathrm{CaO}-\mathrm{Al}_{2} \mathrm{O}_{3}-\mathrm{SiO}_{2}$.

droplet assumes again an almost spherical shape.

The reactions taking place between slag and metal are characterized by three transport steps, see Fig. $\mathbf{2 0}^{17,18)}$ : - a flux of oxygen in the slag towards the interface

- a flux of oxidizable element (here Al) in the metal towards the same interface

- a flux of the oxide product of the reaction, diluting itself in the slag.

In order to compare the results of the various systems investigated, it was chosen to express reaction rates in terms of equivalent flux of oxygen, assuming stoichiometric reactions, as for example:

$2 \underline{\mathrm{Al}}+3(\mathrm{O})_{\text {slag }} \rightarrow \mathrm{Al}_{2} \mathrm{O}_{3}$ leads to equivalent $\dot{n}(\mathrm{O})=\frac{3}{2} \dot{n} \underline{\mathrm{Al}}$

where $\dot{n} \mathrm{Al}$ is the overall flux of the oxidizable element leaving the metallic phase. ${ }^{18)}$

Results of such calculations, combined with interfacial tension estimates lead to the following conclusions:

- for the (various) systems which were studied at IRSID ${ }^{18)}$ interfacial forces seem to disappear when the oxygen flux $\dot{n}(\mathrm{O})$ is larger than $0.1 \mathrm{~g} \cdot \mathrm{atm} \cdot \mathrm{m}^{-2} \mathrm{~s}^{-1}$;

- for values of this flux $\dot{n}(\mathrm{O})$, lower than $0.01 \mathrm{~g} \cdot \mathrm{atm}$. $\mathrm{m}^{-2} \mathrm{~s}^{-1}$, the interfacial tension rapidly recovers high values, often very close to the ones measured at equilibrium;

- differences in chemical potentials between the two phases should be very large, in the initial state. For example, in the case of the system $\mathrm{Fe} \mathrm{Al}$ alloy and silicate slag, the $\mathrm{SiO}_{2}$ content of the slag and the $\mathrm{Al}$ content of the metal should initially be both high enough $\left(\mathrm{SiO}_{2}>20 \%, \mathrm{Al}>2 \%\right)^{18)}$;

- the reaction should not be blocked by accumulation of reaction products at the interface: this passivation can be more sensible when these products are very viscous or solid.

Interfacial Turbulence - Marangoni Effect

As early as 1855 , Thomson ${ }^{62)}$ described the spreading of a drop of alcohol on the surface of water and suggested properly that the observed phenomenon was due to local differences in surface tension. But 16 years later, an Italian scientist, Marangoni, ${ }^{63)}$ interpreted correctly similar phenomena and referring to earlier publications, he likely claimed the right to be considered as the first in this field. Such interfacial motion has now come to be known as the "Marangoni effect".

Since these ancient days, spontaneous interfacial convection has been found to exist in a great number of systems, involving particularly aqueous and organic substances, ${ }^{37,64-66)}$ but also in systems of interest to the process metallurgist. $38,67,68,39,69)$. A mathematical analysis of hydrodynamic instability related to interfacial turbulence has been detailed by Sternling and Scriven ${ }^{37}$ and will not be described here.

In fact, it is difficult, when considering interfacial phenomena taking place during mass transfer, to separate three mechanisms ${ }^{17)}$ :

- lowering of effective interfacial tension

- spontaneous emulsification by diffusion and precipitation

- hydrodynamic phenomena originating from interfacial tension gradients on the interface, which are considered as real "Marangoni effects", but are also often contributing to the two precedent processes.

Motion of liquid induced by Marangoni effect (Marangoni flow or convection) can be described by the interface shear stress $\tau$ in the direction $x^{69)}$ :

$$
\tau=\frac{d \gamma}{d x}=\frac{\partial \gamma}{\partial T} \cdot \frac{d T}{d x}+\frac{\partial \gamma}{\partial C} \cdot \frac{d C}{d x}+\frac{\partial \gamma}{\partial E} \cdot \frac{d E}{d x}
$$

This relation indicates that the interfacial tension gradient is directly related to the gradients of temperature $T$, concentration $C$ of the surface active component and electric potential $E$ at the interface.

Without any source of mechanical energy, spontaneous interfacial movements may occur, the driving force being the difference in interfacial tension between adjacent regions.

The eddies resulting from interfacial turbulence are oriented towards zones having the highest interfacial tension.

The main result of the Marangoni effect in metallurgical process is the increase of the mass transfer coefficient of metallurgical reactions by a factor of several units. ${ }^{18,39)}$ But on account of the complexity of these phenomena, it seems now of particular importance to substantiate the occurrence of Marangoni effect in steelmaking processes and to quantify its contribution.

\section{Applications to Iron and Steelmaking Processes}

As mentioned previously, numerous steps of the steel production are dependent on interfacial phenomena, but only a few examples will be given here. 


\subsection{Hot Metal Refining in Oxygen Converters}

The very essence of the BOF process is its speed, ${ }^{28)}$ the Kinetics of this process depending essentially of the formation of considerable reacting interfaces, producing a tremendous quantity of $\mathrm{CO}$ bubbles, general attention was drawn, some 35 years ago, to emulsifying of the metal in slag and also to slag foaming. Kozakevitch produced very detailed analysis of such phenomena. ${ }^{13,27,28)}$

He has shown that during the early stages of the blow, the stabilization of the metal in slag emulsion is due to adsorption phenomena and to mass transfer through the reacting interface. In later stages, slag crystallization (in silicates or silicophosphates) could be the cause of overrunning. ${ }^{27,28)}$

In the original LD top blowing process, metal and slag were remaining out of equilibrium till the end of the blow and often causing slag overflow. More recently developed combined top and bottom blowing processes, as LBE, permit to approach equilibrium more closely and to avoid this drawback.

Another example of the important role of surface behaviour is deduced from the results obtained by Gaye and Grosjean ${ }^{70)}$ in a LBE pilot converter: as shown in Fig. 21, observed decarburization is much lower when, after the oxygen blow, a bottom injection of oxidizing gas (air), rather than nitrogen, is made, the injected oxygen contributing to increase the interface contamination.

\subsection{Slag Foaming in Other Pyrometallurgical Processes}

Besides basic oxygen steelmaking, the slag foaming phenomenon is also observed in pretreatment of hot metal and bath smelting of iron and chromium ores. ${ }^{29)}$

Slag foaming is particularly vigourous when $\mathrm{CO}$ gas bubbles are very fine (less than $2 \mathrm{~mm}$ in diameter) and that the slag contains surface active components such as $\mathrm{SiO}_{2}, \mathrm{P}_{2} \mathrm{O}_{5}$ or $\mathrm{CaF}_{2}$ (see Chap. 2) which stabilize slag films. The mechanism of the stabilization is now considered to be largely a surface tension driven flow, namely the Marangoni effect. ${ }^{29)}$ It was confirmed that the addition of carbonaceous material (as coke), which is not wetted by slag, may limit or even suppress slag foaming. ${ }^{29,71)}$

\subsection{Inclusions Removal ${ }^{73)}$}

The contact angle value $\theta$ between liquid metal and solid oxide allows to discriminate between easy or improbable inclusion cluster formation, ${ }^{14,32)}$ and to evaluate the stable position in the partial emersion of an inclusion at a free surface.

This wetting angle $\theta$ should be larger than $90^{\circ}$, which is the case of most of the pure oxides except $\mathrm{TiO}_{2}$ and $\mathrm{Cr}_{2} \mathrm{O}_{3}$ (see Sec. 2.3.1 and Ref. 72)), to build possible clusters since two inclusions in contact present to the liquid metal a smaller interface than when they are isolated. The free energy required to separate them is (per surface unit):

$$
\Delta G=2 \gamma_{m} \cos \theta \quad\left(\gamma_{m} \text { is the metal surface tension. }\right)
$$

Some 12 years ago, IRSID experiments have concerned

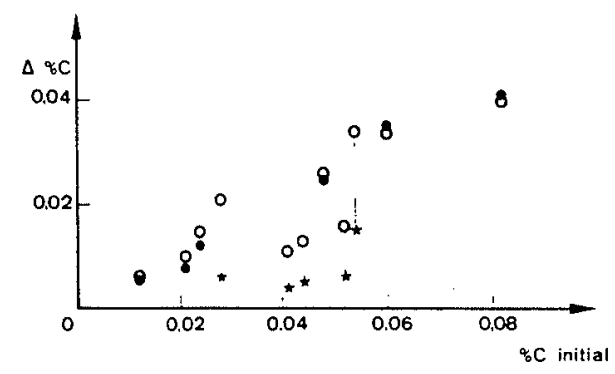

Fig. 21. Change in carbon content during metallurgical stirring with nitrogen $(\bullet)$ or air $(*)$ and theoretical values for inert gas injection $(O)$ (6t pilot conveter)

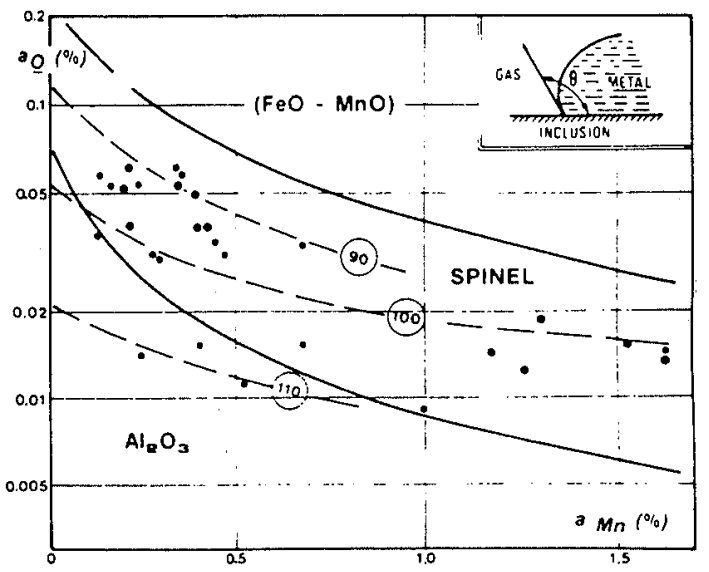

Fig. 22. Lines of equal value of contact angle $(90,100$ and 110 degrees on the dashed lines) between $\mathrm{Fe}-\mathrm{Mn}-\mathrm{O}$ alloys and alumina or spinel at $1600^{\circ} \mathrm{C}$. Solid lines are delimiting fields of stable oxides.

the influence of oxygen activity on the contact between iron-manganese alloys and alumina or spinel $\mathrm{Al}_{2} \mathrm{O}_{3}-$ $(\mathrm{Mn}-\mathrm{Fe}) \mathrm{O} .{ }^{72)}$ Results are presented in Fig. 22.

When the oxygen content is low $(<0.013 \%)$, the contact angle value is always large and cluster formation is possible. For larger oxygen contents which could correspond, for example, to reoxidation of $\mathrm{Al}$ killed alloys, cluster formation may become impossible:

$$
\begin{aligned}
& \underline{\mathrm{O}}>0.036 \% \text { at } 0.6 \% \mathrm{Mn} \text { and } \\
& \underline{\mathrm{O}}>0.055 \% \text { at } 0.28 \% \mathrm{Mn}
\end{aligned}
$$

In intermediate cases, for contact angles slightly larger than $90^{\circ}$, surface forces may not be strong enough to maintain the contact between elementary inclusion particles.

But to increase the relative proportion of the emersed part of the clusters, $\theta$ should also be as large as possible (see Fig. 23).

The most spectacular case demonstrating the importance of contact angle is the emersion of alumina inclusions from Tellurium containing steel: $\theta \approx 160-$ $170^{\circ} .^{55)}$ It was observed by Gatellier ${ }^{74)}$ that alumina clusters and dendrites were floating out of the slag-free. surface metal containing Tellurium.

\subsection{Nozzle Clogging}

The blockage of tundish nozzles during the casting of Al killed steels or any steels containing solid reaction products is still a significant problem. ${ }^{75-77)}$ It is driven 

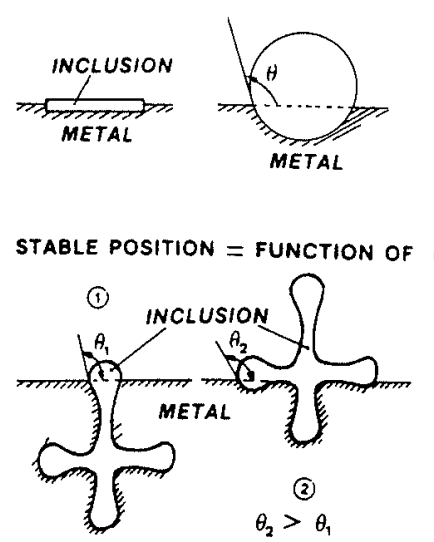

Fig. 23. Stable position of emersion for solid inclusions: influence of contact angle for different shapes.

by inclusion precipitation and growth, followed by separation at the liquid metal/refractory interface, according mainly to mechanisms mentioned above.

An interesting example of such phenomena was very recently described in the case of stainless steels containing $\mathrm{Ti}^{{ }^{77)}}$ : the steel flow rate from the casting ladle decreased with increasing $\mathrm{Ti}$ content and this was due to the build-up of TiN particles in the teeming hole (the contact angle for $\mathrm{TiN}$ has been found to be around $130^{\circ} .^{14)}$

To overcome these difficulties, several approaches have been proposed ${ }^{78)}$ :

- a better control of the number of inclusions in liquid metal, ${ }^{77)}$

- an improved geometry and surface roughness of the nozzle, ${ }^{78)}$

- the use of new ceramic materials which could inhibit inclusion adhesion. ${ }^{78)}$

A lot of work is still certainly necessary in this field.

\subsection{Preferential Attack of Refractories}

Enhanced erosion of refractory materials at metal/ gas, metal/slag and slag/gas interfaces is a well known phenomenon in metallurgical systems (converters, tundish refractories, pouring tubes...).

Careful observations, made by Lucas et al. ${ }^{34)}$ of the boundary line solid oxide (pure $\mathrm{Al}_{2} \mathrm{O}_{3}$ )-liquid metal (pure iron)-gas (Argon $+5 \% \quad \mathrm{H}_{2}$ ) during a study of contact angles by the sessile drop method, induced to propose a mechanism involving the fast surface diffusion of the metallic element (Al) constituting the main oxide phase of the refractory material. A schematic representation is proposed on Fig. 24.

Mukai and co-workers ${ }^{35,69,79,80)}$ have studied intensively local corrosion of various refractory materials by metals and slags. An example is given on the Fig. 25. For these authors, the local corrosion of solid oxide $\left(\mathrm{SiO}_{2}\right)$ at the slag surface is caused by a Marangoni flow of slag $\left(\mathrm{PbO}-\mathrm{SiO}_{2}\right)$ film formed on the surface of solid oxide. Differences in $\mathrm{SiO}_{2}$ content between upper and lower parts of the film cause a surface tension gradient resulting in this Marangoni flow.

In this field, there is a relatively large number of theoretical or laboratory studies, but it should be necessary to follow them with a scientific analysis of industrial observations.

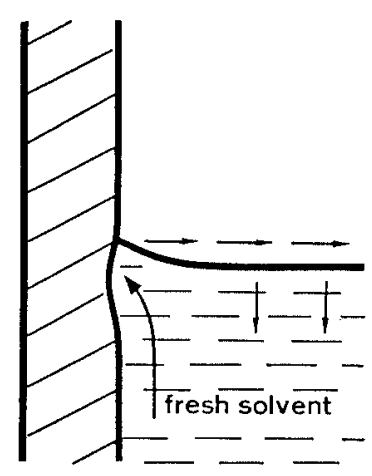

Fig. 24. Schematic representation of possible mechanism of preferential attack by surface diffusion.

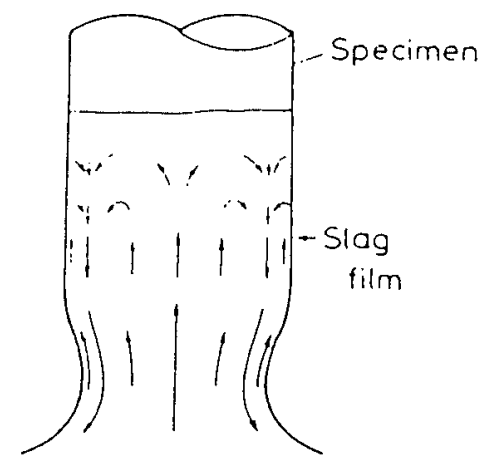

Bulk slog

Fig. 25. Typical flow pattern of slag film on a cylindrical silica specimen $6 \mathrm{~mm}$ dia. immersed in $\mathrm{PbO}-\mathrm{SiO}_{2}$ slag.

\section{Conclusions}

An expansion of vigourous approach of process control of the successive steps of steel production suppose a satisfactory knowledge of kinetics of heterogeneous metallurgical reactions. The purpose of this presentation was to show that these last 30 or 40 years, a lot of work has been done to collect informations on surface and interface properties of the various phases involved, but the challenges, iron and steel makers will face in the next decades, impose to extend this investigation of surface phenomena, which are responsible of enhancing, but also of limitation of kinetics of processes $^{81)}$ :

- to improve automation and quality control of existing processes

- to succeed in developing new or future processes:

- reduction smelting

- near net shape casting

\section{Acknowledgements}

Many thanks are due to the Direction and colleagues from IRSID for their help, and particularly to Henri Gaye, for many fruitful discussions during the preparation of this paper.

\section{REFERENCES}

1) L. S. Darken: Basic Open Hearth Steelmaking, 2nd ed., AIME, New York (1951), Chap. 22.

2) L. S. Darken: The Physical Chemistry of Steelmaking Conf., ed. 
by J. F. Elliott, Technology Press. M.I.T., (1958), 101.

3) J. F. Elliott: Proc. Darken Conf. on Physical Chemistry in Metallurgy, US Steel Corp. Res. Lab., Monroeville, (1976), 209.

4) P. Kozakevitch: Rev. Metall., 46 (1949) $\mathrm{N}^{\circ} 8,505 ; \mathrm{N}^{\circ} 9,572$.

5) P. Kozakevitch and G. Urbain: J. Iron Steel Inst., 186 (1957), 167.

6) P. Kozakevitch: Proc. Nat. Phys. Lab. Sym., 4-6 June 1958, Paper $\mathrm{N}^{\circ} 1 \mathrm{E}, 1$.

7) P. Kozakevitch: Physico Chemical Measurements at High Temperatures, ed. by J O'M Bockris, J. L. White and J. D. Mackenzie, Butterworth Sc. Publ., London, (1959), ch. 9, 208.

8) P. Kozakevitch and G. Urbain: Mém. Scient. Rev Métall., T 58 (1961), $\mathrm{N}^{\circ} 6,401 ; \mathrm{N}^{\circ} 7,517 ; \mathrm{N}^{\circ} 12,931$.

9) P. Kozakevitch: Liquids: Structure, Properties, Solid Interactions, ed. by T. J. Hughel, Elsevier Publ. Co., Amsterdam, (1965), 243.

10) P. Kozakevitch: Brunel University Symp., London, Sept. 1967; Surface Phenomena in Metals, Soc. of Chem. Ind., London, (1968), Monograph 28, 223.

11) P. Kozakevitch, S. Chatel, G. Urbain and M. Sage: Rev. Métall., 52 (1955), N'2, 139; P. Kozakevitch, G. Urbain and M. Sage: Rev. de Métall., T 52 (1955), $\mathrm{N}^{\circ} 2,161$.

12) P. Kozakevitch, G. Urbain and M. Sage: Coal Trades Rev., $T$ 170 (1955), 963.

13) P. Kozakevitch: The Physical Chemistry of Steelmaking Conf., ed. by J. F. Elliott, Technology Press M.I.T., (1958), 89 and discussion, 134.

14) P. Kozakevitch and L. D. Lucas: Rev. Métall., T 65 (1968), $\mathrm{N}^{\circ} 9$, 589.

15) J.-L. Bretonnet, L.-D. Lucas and M. Olette: C. R. Acad. Sc. Paris, t280, série C 21, Mai 1975, 1169; t 285, série C 11, July 1977, 45.

16) H. Gaye and L.-D. Lucas: Cong. "Physicochimie et Sidérurgie", Versailles, Octobre (1978), 57.

17) P. V. Riboud and L.-D. Lucas: Canad. Metall. Q., 20 (1981), $\mathrm{N}^{\circ} 2$, 199.

18) H. Gaye, L.-D. Lucas, M. Olette and P. V. Riboud: C.I.M. Int. Symp. on Interface Phenomena in Metallurgical Systems, Hamilton, August, 1981; Canad. Metall. Q.,23(1984), N², 179.

19) F. D. Richardson: Metall. Trans., 2 (1971), 2747.

20) F. D. Richardson: Physical Chemistry of Melts in Metallurgy, Vol. 2, Academic Press., London, (1974).

21) A. W. Cramb and I. Jimbo: Proc. W. O. Philibrook Memorial Symp., Toronto, April (1983), 259; Iron Steelmaker, June (1989), 43.

22) I. Jimbo and A. W. Cramb: Proc. Sixth Int. Iron and Steel Cong., ISIJ, Tokyo, (1990), 499.

23) M. Tokuda: ISIJ Int., 32 (1992), 1.

24) H. W. Meyer, W. F. Porter, G. C. Smith and J. Szekely: J. Met., 20 (1968), 35

25) P. Kozakevitch and P. Leroy: Rev. Métall, 51 (1954), N³, 203.

26) P. Kozakevitch, G. Urbain, B. Denizot and H. Marette: Proc Cong. Int. sur les Aciéries à l'oxygène, Le Touquet, Sept. (1963), 248.

27) P. Kozakevitch: AIME National Open Hearth Conf., Toronto, April (1969); J. Met., July (1969), 64.

28) G. H. Geiger, P. Kozakevitch, M. Olette and P. V. Riboud: BOF Steelmaking, Vol. 2, chap. 5: Theory of BOF Reaction Rates, ed. by J. M. Gaines, AIME, New York, (1975).

29) S. Hara and K. Ogino: ISIJ Int., 32, (1992), 81.

30) Y. Ogawa, M. Katayama, H. Hirata, N. Tokumitsu and M. Yamaochi: ISIJ Int., 32 (1992), 87.

31) P. Kozakevitch and G. Urbain: Mém. Scient. Rev. Métall., T 60 (1963), N $2,143$.

32) P. Kozakevitch and M. Olette: Clean Steel. Int. Conf., Iron and Steel Inst. Publ. 134, London (1972), 42; Rev. de Métall., T 68 (1971), $N^{\circ} 10,635$.

33) M. Olette: $5^{\circ}$ journée Intern. de la Sidérurgie, ATS Paris, October 1976; Rev. de Métall., (1977), N4, 217.

34) L. D. Lucas, M. Olette and P. Kozakevitch: The Richardson Conf., July 1973; Proc. Inst. of Mining and Metallurgy, ed. by J. H. E. Jeffes and R. J. Tait, London, (1974), 187.

35) K. Mukai, K. Gouda, J. Yoshitomi and K. Hiraguschi: 3rd Int Conf. Molten Slags and Fluxes; Glasgow, June 1988; Proc. The Inst. Met., London, (1989), 215.

36) A. F. Dick, R. J. Pomfret and K. S. Coley: 4th Inter. Conf. on
Molten Slags and Fluxes, Sendai, June 1992; Proc. Tohoku Univ., Sendai, (1993), 380.

37) C. V. Sternling and L. E. Scriven: Am. Inst. of Chem. Eng. J., T 5 (1959), $\mathrm{N}^{\circ} 12,514$

38) J. K. Brimacombe: Physical Chemistry of Process Metallurgy, The Richardson Conf., July 1973; Proc. Inst. of Mining and Metallurgy, ed. by J. H. E. Jeffes and R. J. Tait, London, (1974), 175.

39) P. Hammerschmid: Stahl u Eisen, $\mathbf{T} 107$ (1987), N², 61.

40) C. P. Broadbent, G. Tsotridis, E. D. Hondros and H. Rother: 4th Int. Conf. on Molten Slags and Fluxes, Sendai, June 1992, Proc., 370 .

41) M. Olette: Steel Res., T 59 (1988), N6, 246

42) K. Ogino, A. Nishiwaki and K. Nogi: Special Report No25, The 6th Japan USSR Joint Symp. on Physical Chemistry of Metallurgical Processes, (1977), 1.

43) Handbook of Chemistry and Physics, Surface Tension of Liquid Elements, F24, Chem. Rubler Co. CRC Press Inc. 63rd, ed. by Boca Raton, Flor. (1982-1983).

44) I. Jimbo and A. W. Cramb: ISIJ Int., 32 (1992), 26

45) J. Schade, A. McLean and W. A. Miller: Hume-Rothery Memorial TMS-AIME Symp., New Orleans, March 1986, Proc., 233.

46) K. Nakashima and K. Mori: ISIJ Int., 32 (1992) 11.

47) A.Kasama, A. McLean, W. A. Miller and M. J. Ward: Can. Met. $Q ., 22$ (1983), 9.

48) B. J. Keene: Report DMA (67), Nat. Phys. Lab., Teddington, (1983).

49) F. A. Halden and W. D. Kingery: J. Phys. Chem., 59 (1955) June, 557.

50) K. Ogino, S. Hara, T. Miwa and S. Kimoto: Tetsu-to-Hagané, 65 (1979), 2012

51) G. R. Belton: Metall. Trans., B, 7B (1976), March, 35.

52) S. I. Popel, B. V. Tsarevskii, V. V. Pavlov and E. L. Furman: Izv. Akad. Nauk SSSR Metall., 4 (1975), 54.

53) P. P. Evseev and A. F. Filippov: Izv. V. U. Z. Chern. Met., 10 (1967), 55.

54) B. J. Keene and K. C. Mills: Nat. Phys. Lab. Report Chem. 60, Teddington, U.K., November 1976; B. J. Keene: Nat. Phys. Lab. Report Chem. 63, Teddington, U.K., February 1977.

55) K. Ogino, K. Nogi and O. Yamase: Tetsu-to-Hagané, 66 (1980), 179; K. Nogi and K. Ogino: Can. Metall. Q., 22 (1983), 19.

56) T. El Gammal and P. Stracke: 3rd Int. Conf. on Molten Slags and Fluxes, Glasgow, June 1988; Proc. the Institute of Metals, London, (1989), 207.

57) Yu. A. Minaev and V. A. Grigorian: Zavods. Lab., 31 (1965), 809.

58) A. A. Deryabin, S. I. Popel and L. N. Saburov: Izv. Ak. Nauk. SSSR Metall., 5 (1968), 51.

59) H. Ooi, T. Nozaki and Y. Yoshii: Tetsu-to-Hagané, 58 (1972), 830; Trans. Iron Steel Inst. Jpn., 14 (1974), No9, 9.

60) R. Defay, A. Sanfeld and A. Steinchen: J. Chimie Physi., 69 (1972) $\mathrm{N}^{\circ} 9,1374,1380$.

61) R. Defay and A. Sanfeld: J. Chimie Physi., 70 (1973), N ${ }^{\circ} 9,895$; An. Qhim., 71 (1975), $\mathrm{N}^{\circ} 11-12,856$.

62) J. Thomson: Phil. Mag., 10 (1855), Ser. 4, 330.

63) C. Marangoni: Ann. Phys. Chem., 143 (1871), 337.

64) J. B. Lewis: Chem. Enging. Sci., 3 (1954), 260.

65) T. K. Sherwood and J. C. Wei: Ind. Enging. Chem., 49 (1957), 1030.

66) H. Sawistowski: Chem. Ing. Tech., 45 (1973), 1093, 1114; Ind. Chem. Eng., 15 (1973), 35.

67) J. K. Brimacombe and F. Weinberg: Metall. Trans., 3 (1972), 2298.

68) R. G. Barton and J. K. Brimacombe: Metall. Trans. B, 7B (1976), 144.

69) K. Mukai: ISIJ Int., 32 (1992), 19.

70) H. Gaye and J. C. Grosjean: 65th Steelmaking Conf. of AIME, Pittsburgh, March 1982, 14.

71) Y. Ogawa, H. Katayama, H. Hirata, N. Tokumitsu and M. Yamauchi: ISIJ Int., 32 (1992), 87.

72) P. V. Riboud and M. Olette: Invited paper to the 7th Int. Conf. on Vacuum Metallurgy, Tokyo November 1982; Proc. ISIJ Tokyo, 879

73) J. K. Brimacombe and A. W. Cramb: 6th Int. Conf. on Refining 
Processes (Scaninject VI), Luleå, Sweden, June 1992; Proc. Part 1, Mefos 71.

74) C. Gatellier: Personal communication, unpublished results.

75) M. Anderson and O. Wijk: 6th Int. Conf. on Refining Processes (Scaninject VI), Luleå, Sweden, June 1992, Proc. part 2, Mefos 175.

76) W. Fix, H. Jacobi and K. Wünnenberg: Steel Res., 64, (1993), $N^{\circ} 1,71$.

77) M. Rajaniemi: 6th Int. Conf. on Refining Processes (Scaninject VI), Luleå, Sweden, June 1992; Proc. part 2, Mefos 157.
78) A. McLean: 6th Int. Conf. on Refining Processes (Scaninject VI), Luleå, Sweden, June 1992; Proc. part 2, Mefos 139.

79) K. Mukai, J. M. Toguri and J. Yoshitomi: Can. Met. Q., (1987), 265.

80) K. Mukai: 4th Int. Cof. on Molten Slags and Fluxes, Sendai, June 1992; Proc. 364

81) P. J. Koros, C. J. Bingel and T. H. Bienoser: 6th Int. Conf. on Refining Processes (Scaninject VI), Luleå, Sweden, June 1992; Proc. part 1, Mefos 7. 